\title{
Nieznane fakty z biografii Romana Aftanazego (1914-2004)
}

Zarys treści: Artykuł omawia nowe ustalenia dotyczące biografii Romana Aftanazego (1914-2004), historyka, dokumentalisty i wieloletniego kustosza Biblioteki Zakładu Narodowego im Ossolińskich we Lwowie, a następnie we Wrocławiu, zajmującego w historiografii polskiej niezwykłe miejsce, jako autora pomnikowego opracowania o siedzibach ziemiańskich dawnych ziem wschodnich Rzeczypospolitej: Materiały do dziejów rezydencji, t. 1-11, Warszawa 1986-1991 oraz drugie, uzupełnione wydanie tej pracy: Dzieje rezydencji na dawnych kresach Rzeczypospolitej, t. 1-11, Wrocław 1991-1997.

Outline of content: This article discusses the new findings regarding the biography of Roman Aftanazy (1914-2004), historian, documentalist and long-standing curator of the National Ossoliński Institute Library (initially in Lviv, then in Wrocław), who played an important role in Polish historiography as the author of a monumental study on the residences of Polish landed gentry in the former eastern territories of the Polish-Lithuanian Commonwealth: Materialy do dziejów rezydencji, v. 1-11, Warsaw 1986-1991, and the extended $2^{\text {nd }}$ edition: Dzieje rezydencji na dawnych kresach Rzeczypospolitej, v. 1-11, Wrocław 1991-1997.

Słowa kluczowe: Roman Aftanazy, Włodzimierz Roman Aftanasow, Ksawery Niedobitowski (1914-2004), ziemiaństwo polskie, historia architektury, Litwa, Białoruś, Ukraina, Ossolineum

Keywords: Roman Aftanazy, Włodzimierz Roman Aftanasow, Ksawery Niedobitowski (1914-2004), polish landowners, history of architecture, Lithuania, Belarus, Ukraine, Ossolineum

W ubiegłym roku minęła dziesiąta rocznica śmierci Romana Aftanazego, ale także inna ważna rocznica związana $\mathrm{z}$ tym historykiem - 100-lecie jego urodzin. Przypomnienie tych dat może być okazją do rozszerzenia naszej wiedzy na temat biografii wrocławskiego historyka, a jednocześnie zachętą do pewnych podsumowań. Aftanazy zajął w historiografii polskiej miejsce niepoślednie jako autor bardzo ważnego, wręcz pomnikowego opracowania do dziejów dawnych kresów wschodnich Rzeczypospolitej ${ }^{1}$. Zebrał, opracował i wydał drukiem materiały o siedzibach

1 Materialy do dziejów rezydencji, t. 1-11, Warszawa 1986-1991 i drugie uzupełnione wydanie tej pracy pt. Dzieje rezydencji na dawnych kresach Rzeczypospolitej, t. 1-11, Wrocław 1991-1997. 
ziemiańskich i ich właścicielach na tych terenach. Publikacja najważniejszego dzieła naukowego historyka przypada na końcowy etap jego życia, który doczekał się już wstępnego omówienia w literaturze i prasie współczesnej, natomiast znacznie mniej wiemy z dotychczas opublikowanych szkiców biograficznych Aftanazego o początku jego zainteresowań i aktywności naukowej ${ }^{2}$. W tej części życiorysu historyka nadal jest dużo luk i niejasności. Na wyjaśnienie niektórych pozwalają dokumenty z archiwum historyka, zdeponowanego w Ossolineum, ale nie odpowiadają one na wszystkie wątpliwości. Pozostaje wiele szczegółów wymagających dalszych poszukiwań.

W prezentowanym artykule skupię się na kilku faktach $\mathrm{z}$ bogatej biografii wrocławskiego historyka, sięgając do przedwojennego i wojennego życiorysu Aftanazego. Ale zaczynając od początku, na chwilę oddam głos naszemu bohaterowi, który w swojej niedrukowanej autobiografii napisał: „Urodziłem się dnia 2 kwietnia 1914 r. w miejscowości uzdrowiskowej Morszyn k. Stryja w ówczesnej Galicji Wschodniej z ojca Jana i matki Olimpii Kraśnik-Rzepeckiej. W kilka miesięcy po wybuchu pierwszej wojny światowej i inwazji rosyjskiej, ojciec mój, jako urzędnik kolejowy wraz z innymi kolejarzami ewakuowany został w głąb Austrii. Na jakiś czas osiadł w małej podalpejskiej miejscowości Eisenerz ${ }^{3}$, ale po cofnięciu się wojsk rosyjskich wrócił do swych obowiązków w Morszynie. Moja matka ze mną jedynakiem pozostała jednak w Austrii do końca wojny". Przytaczany tekst powstał przy końcu życia historyka w 1997 r. i generalnie jest spójny z zachowanymi dokumentami ${ }^{4}$, poza drobnym szczegółem, że przy nazwisku panieńskim matki autora pojawia się drugi człon „Rzepecka”, którego nie ma w metryce Aftanazego ${ }^{5}$. Na uwagę też zasługuje fakt, że relacja dotycząca rodziców, ogranicza do tego krótkiego wspomnienia, nie wiemy, co się z nimi stało, czy dożyli kolejnej wojny, czy Aftanazy miał jakiś jeszcze poza nimi krewnych. W innym miejscu historyk tylko nadmienia, że w latach 30. dostał od matki aparat fotograficzny, który wykorzystywał później w swoich pracach dokumentacyjnych. Z kolej Andrzej Baranowski, historyk sztuki, długoletni

Oprócz tego Aftanazy opublikował jeszcze m.in.: Emanuel Małyński, Polski Słownik Biograficzny, t. XIX, s. 457-458; Pacyków - nieznane polskie echo rezydencji Villa Rotonda, „Przegląd Wschodni” (dalej cytuję w skrócie: PW), 2000, t. VII, z. 1 (25), s. 206-213; Tahańcza: uzupełnienie do dziejów: „Dziejów rezydencji na dawnych kresach Rzeczypospolitej”, PW, 2000, t. VII, z. 1 (25), s. 212-213; Itga i Posiń: dwie nieznane rezydencje polskie w Inflantach, PW, 2004, t. IX, z. 1 (33), s. 216-222. Zob. też Tadeusz Epsztein, Wołyń, Podole i Ukraina w „Materiałach do dziejów rezydencji” Romana Aftanazego, „Kwartalnik Historyczny”, R. C, z. 2/1993, s. 99-104; Jeszcze o „Materiałach do dziejów rezydencji”. Odpowiedź na list Romana Aftanazego, „Kwartalnik Historyczny”, R. C, z. 3/1993, s. 179-180 i Roman Aftanazy, Odpowiedź Tadeuszowi Epszteinowi, „Kwartalnik Historyczny”, R. C, z. 3/1993, s. 175-178.

2 Dotychczas ukazało się tylko kilka krótkich biografii Romana Aftanazego, m.in. zob. Stanisław Mossakowski, Przedmowa, [w:] Roman Aftanazy, Dzieje rezydencji na dawnych kresach Rzeczypospolitej, t. 1, Wrocław 1991, s. 7-10; Andrzej Baranowski, Roman Aftanazy 1914-2004, PW, 2004, t. IX, z. 3 (35), s. 763-766; Tadeusz Epsztein, Wspomnienie o Romanie Aftanazym (1914-2004), „Studia z Dziejów Rosji i Europy Środkowo-Wschodniej”, 2005, t. XL, s. 354-357.

3 Eisenerz - miasto w Styrii (Austria).

4 Zob. „Moje curriculum vitae”, s. 1, [w:] Dokumenty osobiste Romana Aftanazego, Biblioteka Zakładu Narodowego im. Ossolińskich we Wrocławiu (dalej: Ossolineum), sygn. akc. 89/2005.

5 Ibidem. 
współpracownik historyka i współredaktor pierwszego wydania dzieła Aftanazego, nadmienia, że ojciec Romana, miał 56 lat, jak urodził mu się syn jedynak, czyli niewykluczone, że mógł umrzeć przed 1939 roku$^{6}$.

„Do szkoły powszechnej uczęszczałem początkowo w Morszynie, a następnie w Stryju” - wspomina dalej Aftanazy. „W tymże mieście w 1935 r. ukończyłem gimnazjum klasyczne dawnego typu"7. Z innych relacji wiemy, że jeszcze będąc w szkole, zaczął jeździć na wakacje na Polesie do Nowoszyc, do majątku Ordów, gdzie narodziła się jego pasja historyka-dokumentalisty siedzib ziemiańskich ${ }^{8}$. Jak wyglądał warsztat naukowy młodego adepta historii, pokazują jego dwa listy z 1939 r., które edytuję poniżej. Aftanazy w tym czasie był już na studiach historycznych, które rozpoczął w 1936 r. na Uniwersytecie Jana Kazimierza we Lwowie na Wydziale Humanistycznym. Wówczas miał już za sobą nie tylko liczne podróże krajoznawcze i zrobione kilkadziesiąt (ok. 70) opisów dworów i pałaców z różnych części ziem kresowych II RP, ale też wiele publikacji na ten temat, ogłaszanych w dodatkach ilustrowanych do prasy codziennej, np. w „AS. Ilustrowanym Magazynie Tygodniowym” (np. 1938, nr 45). W jednym z omawianych listów Aftanazy wspomniał, że jednocześnie pracował nad większym opracowaniem książkowym, w kilku tomach, obejmującym dotychczas zebraną dokumentację, edycję pierwszego tomu zaplanował już na 1939 rok.

Nie wiemy do końca, jak wyglądał formularz pytań, z jakim zwracał do właścicieli zwiedzanych obiektów, ale z pewnością miał już w tym czasie spore doświadczenie, jak należy postępować $\mathrm{z}$ ziemianami, na co zwracać uwagę podczas pierwszych kontaktów, jakie podawać argumenty, aby być przyjętym itd. Aftanazy umiał przy zachowaniu form wymaganych w środowisku ziemiańskim być bezpośrednim, ale

6 A. Baranowski, op. cit., s. 763.

7 „Moje curriculum vitae”, s. 1.

8 „Jako młody chłopiec, uczeń gimnazjum, zaproszony zostałem do jednego z dworów na Polesiu, nazywanych wówczas „kresowymi”. Atmosfera tego starego stylowego dworu w Nowoszycach była niezwykła, gdyż łączyła w sobie harmonijnie wszystkie pozytywne cechy ziemiańskie z intelektualnymi. Pani domu, Maria Ordzina, wdowa po Karolu, była bowiem córką znakomitego historyka, profesora i rektora Uniwersytetu Jagiellońskiego, Stanisława Smolki i Wandy Ordzianki, wnuczką znanego działacza galicyjskiego, Franciszki Smolki, a po matce wnuczką Józefa Kremera, filozofa i historyka sztuki. Już w czasie pierwszej bytności, oczarowany atmosferą jak z powieści Weysenhoffa, Orzeszkowej czy Rodziewiczówny, potraktowany zostałem jako domownik i zaproszony na stałe. Część wakacji spędzałem więc w Nowoszycach każdego roku, aż do sierpnia 1939. Istniała tam bardzo bogata biblioteka, do której Jerzy (Jur) Orda, jeden z trzech synów pani domu, dziś nieomal legendarny historyk kultury i archiwista wileński, nadsyłał wszelkie zasługujące na uwagę nowości z zakresu historii i pamiętnikarstwa. Korzystałem z niej w jak najszerszym zakresie.[...] W pobliżu Nowoszyc znajdował się Mołodów z pięknym klasycystycznym pałacem, wypełnionym starymi meblami, dziełami sztuki i pamiątkami rodzinnymi. Mołodów był własnością pana Konstantego Skirmuntta, ambasadora Polski w Wielkiej Brytanii [...] Tam także często bywałem. W znacznie dalszym sąsiedztwie mieszkała autorka najliczniejszych powieści „kresowych” - Maria Rodziewiczówna. [...] Nowoszyce i Mołodów wywarły więc na mnie wrażenie szczególne. Oczarowany atmosferą obu dworów, w miarę dorastania, zacząłem sobie coraz wyraźniej zdawać sprawę z tego, że światu temu grozi zagłada.[...] Zacząłem więc próby dokumentacji zabytków. Na pierwszy ogień poszły Nowoszyce, Mołodów i Hruszowa [...], a w następnej kolejności dalsze sąsiedztwa”. Cyt. ze wspomnień Aftanazego za: S. Mossakowski, op. cit., s. 7-8. 
i dość stanowczym w dążeniu do celu. Wiedział, że do wielu domów, szczególnie tych bardziej „utytułowanych”, nie zostanie wpuszczony bez odpowiedniej protekcji, więc o taką też się wystarał w osobie ks. Lubomirskiej z Przeworska, powołując się na nią w swoich listach. Kontakty z ziemiaństwem dały mu obok dobrych doświadczeń, tych, które niegdyś zachęciły go do pracy dokumentalisty, też gorsze wrażenia czy wręcz negatywne. Do jednych i drugich nawiązuje w korespondencji. Nie ukrywał, że cześć jego adresatów nie ma zwyczaju odpisywać na listy, a tylko domyślać się możemy, z jakim jeszcze złym traktowaniem mógł stykać się ten młody człowiek.

Wybuch wojny przeszkodził Aftanazemu w kontynuowaniu rozpoczętych prac, a także przerwał jego studia. $W$ jego papierach zachowało się oryginalne zaświadczenie prof. Stanisława Łempickiego z 22 maja 1944 r. (Lwów): „Stwierdzam niniejszym, że p. Włodzimierz Roman Aftanazy, student Uniwersytetu Lwowskiego oddał mi był w czerwcu 1939 r. przed wojną pracę magisterską z historii (specjalny dział: historia oświaty i szkolnictwa) pt. „Szkolnictwo polskie w czasach Księstwa Warszawskiego (1807-1816)”, która uznana została za przyjętą ze stopniem: dobrym. Rękopis pracy zaginął w czasie wojennych działań"9. Aftanazy już przed wojną miał napisaną pracę magisterską, ale studiów nie zakończył. Kontynuował naukę na tajnych kompletach w latach 1939-1941. Ostateczny egzamin miał zdać 24 lipca 1942 r. we Lwowie z wynikiem dobrym, także na czwórkę została oceniona jego praca magisterska, o której już wspomniałem wyżej. Ostatecznie dyplom magistra filozofii w zakresie historii Włodzimierz Roman Aftanazy otrzymał na Uniwersytecie Wrocławskim dn. 15 czerwca 1946 roku $^{10}$.

Nim jednak Aftanazy ostatecznie opuścił Lwów, miały miejsce jeszcze inne ważne wydarzenia w jego życiu: przede wszystkim zmienił nazwisko, przynajmniej do wiosny 1939 r. nazywał się: Aftanasow ${ }^{11}$. Zmianę nazwiska musiał przeprowadzić jeszcze przed samą wojną lub zaraz po jej rozpoczęciu, gdyż w odpisie metryki z grudnia 1939 r. pojawia się już nowe nazwisko. Powód zmiany Aftanazy mimo woli uzasadnia w liście z pisanym w styczniu 1939 r. skierowanym do właściciela majątku Łabuńki na Zamojszczyźnie, podkreśla w nim obcość nazwiska Aftanasow. Nie mamy jednak pewności, czy tylko chęć wtopienia się w środowisko polskie zadecydowała o tym kroku, czy też były inne i może ważniejsze przyczyny. Nie można bowiem wykluczyć, że ostateczna decyzja została podjęta dopiero po wkroczeniu Sowietów do Polski we wrześniu 1939 r., co też łatwo uzasadnić, gdyż u osób wywodzących się z dawnej imigracji rosyjskiej lęk przez bolszewikami był nie mniejszy, a może i jeszcze większy niż u Polaków. Pewnym przygotowaniem do zmiany tożsamości było jeszcze przed 1939 r. używanie przez młodego historyka pseudonimu literackiego Ksawery Niedobitowski, pod którym zaczął publikować swoje artykuły o siedzibach ziemiańskich ${ }^{12}$. Nie tylko nazwisko brzmiące z rosyjska mu przeszkadzało, ale także jego pierwsze imię Włodzimierz. W korespondencji

9 Zob. Dokumenty osobiste..., Ossolineum, sygn. akc. 89/05, b.p.

10 Ibidem.

11 Nazwisko Aftanasow występuje na terenie Galicji, np. Julia Aftanasow, żona Aleksandra Bardiniego (1913-1995), u której ukrywał się po ucieczce z getta we Lwowie.

12 Zob. Dokumenty osobiste... 
z 1939 r., jeszcze przed zmianą nazwiska, Aftanazy używał tylko drugiego imienia: Roman. Ostatecznie jednak dopiero po wojnie całkowicie porzucił pierwsze na rzecz drugiego (1948 r.). Oba fakty nie byłyby niczym dziwnym, gdyby nie całkowite milczenie wokół nich. Można powiedzieć, że tylko przypadek odsłonił ten całkowicie wyparty z biografii historyka wrocławskiego epizod.

Dziś nie ustalimy bezpośredniej przyczyny tych decyzji, ale możemy przyjrzeć się ich konsekwencjom. Aftanazy nigdy nie ujawnił publicznie zmiany swoich personaliów. Także nie zostawił o tym fakcie informacji w zachowanym archiwum. Bardzo skrupulatnie „oczyścił” je z dokumentacji, która mogła zdradzić zmianę nazwiska. Nie do końca zrozumiałe są te starania, ale trudno inaczej podsumować stan archiwum historyka zdeponowanego w Ossolineum. W teczce zawierającej dokumenty osobiste Aftanazego najstarszym dokumentem jest odpis metryki z grudnia $1939 \mathrm{r}$. już z nowym nazwiskiem. Mimo że Aftanazy kilkakrotnie ogłaszał, że zachowały mu się materiały przedwojenne dotyczące jego prac dokumentacyjnych w siedzibach ziemiańskich, nie przekazał do Ossolineum żadnych przedwojennych dokumentów. W swojej pracy opublikował tylko zdjęcia wykonywane przed 1939 rokiem. Co się stało z tymi opisami i listami zebranymi przed 1939 r., czy zostały świadomie zniszczone, czy może jednak, kiedyś ujrzą światło dzienne? W tej całej historii jeden szczegół budzi poważne pytania: Aftanazy w latach 30. korespondował z liczną grupą ludzi, jego listy lądowały w sekretarzykach wielu domów ziemiańskich, biorąc pod uwagę miejsca zamieszkania adresatów, większość tych manuskryptów przepadła po 1 września 1939 r., ale jakaś część ocalała, zawsze było ryzyko, że tajemnica wyda się, czy warto było ten fakt tak ukrywać? Konkluzja jest prosta: Aftanazy miał sporo szczęścia, gdyż nikt za jego życia prawdy nie odkrył, a w każdym razie nie ujawnił. Dopiero po natrafieniu na korespondencję załączoną poniżej zacząłem robić kwerendę w zbiorach publicznych i okazało się, że takich listów może być więcej, ale nie wszyscy muszą od razu skojarzyć, że Włodzimierz Roman Aftanasow = Roman Aftanazy ${ }^{13}$.

Kolejnym interesującym i nieznanym epizodem w biografii Aftanazego jest jego uwięzienie podczas drugiej okupacji sowieckiej. O tym także wspomina w „curiculum vitae”: „W czasie pierwszej okupacji sowieckiej i niemieckiej pracowałem w Morszynie-Zdroju w tamtejszym zarządzie uzdrowiska jako pracownik fizyczny lub biurowy. Pod koniec zimy 1944 r. przez ówczesnego nieoficjalnego dyrektora prof. M[ieczysława] Gębarowicza przyjęty zostałem do pracy w Bibliotece Ossolińskich. W nocy 3 stycznia 1944 r. po ponownym zajęciu Lwowa przez Armię Czerwoną zostałem aresztowany za działalność nielegalną i osadzony w słynnym więzieniu politycznym NKGB przy ul. Łąckiego. Tej samej nocy aresztowano kilka tysięcy innych obywateli Lwowa. Akcja ta miała zmusić lwowian do rejestrowania się na wyjazd na Zachód, do czego nie okazywali żadnej ochoty. Aresztowano mnie na skutek donosu młodego Polaka Jana Skrzetuskiego, pełniącego funkcje łącznika ${ }^{14}$.

13 Zob. Korespondencja Michała Pawlikowskiego, Biblioteka Jagiellońska, rkps, akc. 482/04 (tu: Aftanazow).

14 Agenta sowieckiego? 
Zwolniono mnie zaś w czerwcu tegoż roku ze względu „na brak dostatecznych dowodów winy". Do zwolnienia mnie w zasadniczy sposób przyczynił się Polak pochodzenia z okolic Winnicy - Czapliński, którego imienia już nie pamiętam. Był on moim ostatnim sędzią śledczym, który odpowiednio śledztwem pokierował. Uczynił to na skutek próśb moich znajomych, u których kwaterował, i poręczenia mojej „lojalności” przez prof. Gębarowicza. Po wyjściu z więzienia powróciłem do pracy w Ossolineum, gdzie m.in. przygotowywałem transport książek jako „dar narodu ukraińskiego dla narodu polskiego”. W ramach expatriacji w kwietniu $1946 \mathrm{r}$. wyjechałem do Wrocławia"15.

Powojenne losy Romana Aftanazego są dobrze znane. Jego przedwojenne zainteresowania w żaden sposób nie mieściły się w ramach dozwolonych przez cenzorów PRL. Po pierwsze zajmował się klasą „obszarniczą”, skazaną na wymazanie z historii Polski, po drugie terenami, które w większości oderwano od państwa. Przez długie dziesięciolecia na tematykę ziem wschodnich był ostry zapis cenzury, zezwalającej wyłącznie na wybrane zagadnienia. Aftanazy nie miał wyjścia, jeżeli chciał kontynuować swoją pracę, musiał zejść do podziemia. Przez kilkadziesiąt lat pracował w całkowitej ciszy, prowadząc ogromne badania, korespondencję na własny koszt. Dopiero z czasem Ossolineum zaczęło mu pomagać wykonując odbitki fotograficzne nadsyłanej dokumentacji ikonograficznej. Był niegroźnym dziwakiem. Cierpliwie znosił trudności i niepowodzenia, także kłopoty finansowe, nie licząc specjalnie na druk swojej pracy. Sam nie wierzył, że dożyje publikacji zebranych materiałów. Trzeba podkreślić, że pierwsze wydanie jego dzieła było wyłącznie przeznaczone dla bardzo wąskiego grona specjalistów i rozprowadzane przez Instytut Sztuki na podstawie imiennych list. Dopiero druga edycja, rozpoczęta po przełomie politycznym 1989 r. przyniosła szersze rozpowszechnienie tej pracy.

Do niedawna nic prawie nie wiedziano o spuściźnie archiwalnej, jaka została po Romanie Aftanazym. Będąc we Wrocławiu na początku lat 90., zapytałem Aftanazego o los materiałów, które posłużyły mu do przygotowania Materiałów... Wówczas był bardzo tajemniczy i powiedział, że tylko ma gotowe maszynopisy i dokumentację fotograficzną, a resztę odsyłał do respondentów. Nie przyznał się do przechowywania obszernej korespondencji. Może nie chciał jej za swego życia udostępniać, a może miał inne powody takiej właśnie decyzji. To już w tej chwili nie jest ważne. W każdym razie, gdy kilka lat temu, przeglądając internetowy katalog rękopisów Ossolineum zobaczyłem ogromną kolekcję materiałów po Aftanazym, byłem miło zaskoczony. $Z$ dużą nadzieją wyruszyłem do Wrocławia, snując różne projekcje na temat przyszłych opracowań, jakie będzie można podjąć po wykorzystaniu tych bogatych zbiorów. Nie zostały one jeszcze opracowane, dlatego warto kilka słów powiedzieć o ich zawartości. Można wśród nich wyróżnić kilka odrębnych grup: W pierwszej znajdziemy czystopis (maszynopis) pełnego opracowania Aftanazego, obejmującego poszczególne opisy siedzib. Jest to oczywiście wersja tekstu, która stała się postawą pierwszego wydania pracy w edycji Instytutu Sztuki PAN w latach 1986-1991. Maszynopisy ułożone są podobnie

15 „Moje curriculum vitae”, s. 1-2. 
jak w edycji książkowej - alfabetycznie według poszczególnych województw dawnej Rzeczypospolitej ${ }^{16}$. Drugą serię stanowią źródłowe materiały do opisów siedzib ${ }^{17}$. Jest to głównie dokumentacja, którą Aftanazy otrzymywał od dawnych właścicieli, ich rodzin lub innych osób, znających z autopsji majątki kresowe. Dla historyka te materiały są szczególnie cenne. Składają się na nie: opisy pałaców i dworów, ich wnętrz, zbiorów sztuki, a także parków i ogrodów itd. Czasami znajdziemy tu kopie (odpisy) dokumentów, plany, inwentarze i oczywiście załączoną korespondencję. Niestety, nie ma tu listów Aftanazego, wyłącznie zachowane zostały listy przychodzące ${ }^{18}$. Tylko $\mathrm{z}$ nadsyłanych odpowiedzi możemy wnioskować, jakie pytania i problemy pojawiły się w listach historyka.

Dokumentacja ta, podobnie jak pierwsza część archiwum, została ułożona wg nazw geograficznych siedzib. Należy zwrócić uwagę, że w plikach dotyczących wybranych obiektów znajdziemy także opisy dotyczące innych siedzib, gdyż respondenci Aftanazego przysyłali często dodatkowe materiały i informacje, jakimi dysponowali. Bez przejrzenia całego zbioru nie można zebrać wszystkich przekazów na temat poszczególnych obiektów i osób. Jak radził sobie w tym gąszczu informacji Aftanazy - tego nie wiemy, może miał jakiś skorowidz, pozwalający na lepszą orientację w całym archiwum. Trzecią częścią archiwum są materiały o siedzibach, których opisy nie poszły do druku ${ }^{19}$. Czwartą częścią jest duży zbiór ogólnej korespondencji przychodzącej do historyka, ułożonej w układzie alfabetycznym według nadawców ${ }^{20}$. Nie znamy kryteriów podziału korespondencji Aftanazego, gdyż w zbiorze czwartym też znajdują się informacje o siedzibach ziemiańskich, jednocześnie są listy dotyczące innej tematyki. Zgromadzono tu listy, także od wielu osób znanych, z którymi historyk przyjaźnił się, np. od Andrzeja Baranowskiego, Andrzeja Ciechanowieckiego, Tadeusza Chrzanowskiego, Jana Dowgiałły i innych. W piątej części archiwum wyodrębniono różne materiały, np. dokumentację dotyczącą spraw wydawniczych ${ }^{21}$, korekty i uzupełnienia, adresy osób, z którymi korespondował Aftanazy itd. ${ }^{22}$

Czy zachowane w Ossolineum materiały są kompletne? Jak już wspomniałem, nie natknąłem się w archiwum na dokumentację przedwojenną, o której Aftanazy wspomina w swojej autobiografii ${ }^{23}$. Najstarsze listy sięgają przełomu lat 40 . i 50 ., ale obszerniejsza korespondencja zaczyna się praktycznie od lat 60. Niewątpliwie zebrany materiał jest bardzo cenny i wymaga dalszego wykorzystania, w pierwszym rzędzie porządnego

16 Np. Materiały dot. województwa bracławskiego - Ossolineum, sygn. akc. 65/04; materiały dot. województwa podolskiego - Ossolineum, sygn. akc. 66/04.

17 Ossolineum, sygn. akc. 1-6/04. Każda z sześciu części obejmuje kilka liter alfabetu i została umieszczona w kilku teczkach, razem - 48 teczek.

$18 \mathrm{~W}$ innej kolekcji Ossolineum (sygn. 18377/II) zachował się duży zbiór listów Aftanazego z lat 1955-1984 do Mieczysława Gębarowicza.

19 Ossolineum, sygn. akc. 69/04 - 2 teczki.

20 Kolekcja korespondencji składa się dwóch serii: Ossolineum, sygn. akc. 7-8/04 i 71-75, 77/04 - razem 48 teczek.

21 Ossolineum, sygn. akc. 78/04 - 2 teczki.

22 Ossolineum, sygn. akc. 70/04 - 4 teczki.

23 „Moje curriculum vitae”, s. 3. 
ułożenia i opisania, co jest niezbędne do dalszej pracy nad nim. Już dziś możemy być pewni, że Aftanazy nie wykorzystał wszystkich źródeł i relacji, które otrzymał. W bogatej korespondencji i załączonej dokumentacji znajdziemy wiele jeszcze danych o ogromnej wartości nie tylko na temat samych siedzib, ale również ludzi, którzy nadsyłali materiały. Ich listy mają walor ilustracyjny dla historii środowiska ziemiańskiego z dawnych terenów wschodnich. Grupa ta szczególnie była dotknięta katastrofami XX wieku. Omawiając spuściznę Aftanazego, trzeba podkreślić, że jest ona źródłem nie tylko do dziejów jego pracy, ale także wspaniałym materiałem o charakterze biograficznym ${ }^{24}$. W korespondencji Aftanazego znajdziemy dziesiątki listów od jego przyjaciół i znajomych pełnych szczegółów na temat życia adresata, jego zainteresowań itd. Widać na jej przykładzie, jak kontakty nawiązane $\mathrm{w}$ celu zdobycia informacji do pracy naukowej przerodziły się z czasem w długie przyjaźnie trwające do końca życia historyka. Aftanazy nie mając swojej rodziny, traktował takie osoby jak własnych krewnych, jak osoby bardzo mu bliskie, czego dowodem było podzielenie zgromadzonych w mieszkaniu wrocławskim cennych dzieł sztuki i biblioteki pomiędzy niektórych z tych przyjaciół.

\section{Dokumenty ${ }^{25}$}

\section{List Romana Aftanasowa do właściciela Łabuniek ${ }^{26}$}

Lwów, [ul.] Gródecka 2B m. 5 „Dom Katolicki”27, 15 stycznia 1939 [r.].

Wielce Szanowny Panie,

przepraszam, że adres jest niepełny, ale tu we Lwowie, zwłaszcza, że mam obecnie moc pracy, bardzo mi trudno o zaczerpnięcie jakichś wystarczających wiadomości. Aby nie zabierać Panu niepotrzebnie wiele czasu, przystępuję od razu do sedna sprawy: Od kilku więc lat jeżdżę w wolnych chwilach po Polsce i fotografuję jej zabytkowe rezydencje wiejskie w postaci zamków, pałaców, dworów, aby w niedalekiej już przyszłości wydać o nich obszerną monografię. Będzie ona zawierała dokładne dzieje i opis każdej siedziby, ilustracje zaś będą tylko moje i jak najwięcej ich. Obecnie

24 M.in. ta korespondencja pozwala nam zobaczyć, w jakich warunkach w PRL żył nasz bohater. Z listów jednego z przyjaciół historyka dowiadujemy się, że Aftanazy korzystał z jego pośrednictwa w latach 60., sprzedając książki w antykwariatach warszawskich, aby dorobić do marnej pensji. Zob. Ossolineum, sygn. akc. 71/04/4, b.p.

25 Poniżej edytowane dokumenty (3) zachowane w oryginałach pochodzą ze zbiorów Macieja i Anny Dunin-Łabędzkich z Warszawy, którym serdecznie dziękuję za ich udostępnienie i zgodę na publikację.

26 W tym czasie Łabuńki (pow. zamojski) były współwłasnością rodzeństwa: Andrzeja, Krystyny, Jana i Elżbiety Kołaczkowskich. Nie jest jasne, do kogo imiennie Aftanazy skierował ten list, gdyż nie zachowała się jego koperta. Nie ma jednak wątpliwości, że odpowiedziała na niego Krystyna Kołaczkowska, która w związku z planowanym w lipcu 1939 r. jej ślubem, miała przejąć latem t.r. razem ze swoim przyszłym mężem Maciejem Dunin-Łąbędzkim administrację majątku. Do tego czasu administratorem Łabuniek był pan Rafał Kirkor. Zob. też Ziemianie polscy XX wieku, t. 10, Warszawa 2013, s. 45-49, 65-66.

27 Mieściła się tam m.in. siedziba Towarzystwa św. Stanisława Kostki. 
zajmuję się głównie ziemiami południowo-wschodnimi i na ich terenie fotografowałem już około 70 rezydencji. Opisywałem je i opisuję w Koncernie I.K.C. i Ilustracji Polskiej $^{28}$, podpisując się z powodu niepolskiego brzmienia mojego nazwiska: Ksawery Niedobitowski ${ }^{29}$. Mam nadzieję, że jeśli nie nastąpią jakieś powikłania, będę w tym roku gotów z pierwszym tomem wspomnianego wydawnictwa.

W kwietniu, maju lub czerwcu będę fotografował Klemensów ${ }^{30}$. W tym też czasie pragnąłbym sfotografować Łabuńki, o których słyszałem dużo żywych słów, jak też, jako o bardzo pięknym pałacu czytałem w starym Słowniku geograficznym ${ }^{31}$ czy też w Ruinach Polski dr Szydłowskiego ${ }^{32}$, jako o dworze przez wojnę stosunkowo niezniszczonym.

Proszę też Wielce Szanownego Pana o pisemne pozwolenie na sfotografowanie pałacu zewnątrz i wewnątrz, jeśli Go będę miał przyjemność zastać wówczas w domu, lub tylko zewnątrz, jeśli mnie przyjemność ta ominie. Zapowiedzieć przyjazdu z góry nie mogę, bo to dla mnie wielkie obciążenie. Moje ekskursje odbywam zwykle w ten sposób, że po otrzymaniu pozwolenia czekam na wolną od zajęć uniwersyteckich chwilę, słucham komunikatów radiowych o pogodzie, i jeśli wywnioskuję, że zapowiada się ładna na kilka dni najbliższych, ruszam zaraz do celu. Jeśli zastanę właściciela danego obiektu w domu bardzo się cieszę, jeśli nie, pokazuję służbie pisemne pozwolenie, przystępuję do pracy, a po dokonaniu jej piechotą odchodzę do najbliższej stacji kolei. Ponieważ zaś nie uważam siebie za gościa, lecz za interesanta, sądzę iż takie kwestii rozwiązanie jest najlepsze. Nigdy nie mam w programie zostania w danym dworze dłużej, niż tego wymaga potrzeba dokonania kilku czy kilkunastu zdjęć. W żadnym wypadku dwór nie ponosi z powodu mej pracy ani mej osoby żadnych kosztów, ani obowiązków. Do Łabuniek przyjdę piechotą z Zamościa i tam pewnie odejdę, mieszkając w hotelu.

W związku z tym byłbym Panu bardzo wdzięczny, gdyby mi zechciał udzielić kilku informacji, których skądinąd nie mogę osiągnąć.

Ile jest kilometrów z Zamościa do Łabuniek? Ile do Tomaszowa? Kto jest właścicielem Łabuń? ${ }^{33}$, czy to blisko od Łabuniek? Czy jest w okolicy jakiś inny jeszcze ciekawy dwór?

28 I.K.C. („Ilustrowany Kuryer Codzienny”), popularny dziennik krakowski o zasięgu ogólnopolskim, wydawany w latach 1910-1939 r., średni nakład ok. 250 tys. W Narodowym Archiwum Cyfrowym znajduje się kolekcja fotografii (ok. 188 tys.) z wydawnictwa I.K.C., w tym również zdjęcia wykonane przez Romana Aftanazego (Ksawerego Niedobitowskiego).

29 Niedobitowski, pseudonim nawiązujący do tytułu nowel Marii Rodziewiczówny (1863-1944): Tydzień u Niedobitowskich, Niedobitowscy płacą, opublikowanych w tomie zbiorowym wraz z innymi utworami w pracy Niedobitowscy z granicznego bastionu (Lwów-Poznań 1926), poświęconych m.in. losom kresowego ziemiaństwa.

30 Klemensów (pow. zamojski, obecnie część Szczebrzeszyna), znajduje się tu pałac wzniesiony w XVIII w. dla Tomasza Zamoyskiego (VII ordynata), do 1944 część Ordynacji Zamojskiej.

31 Słownik geograficzny Królestwa Polskiego i innych krajów słowiańskich, t. 1-15, Warszawa 1880-1902.

32 Tadeusz Szydłowski, Ruiny Polski: opis szkód wyrządzonych przez wojnę w dziedzinie zabytków sztuki na ziemiach Małopolski i Rusi Czerwonej, Kraków 1919.

33 Łabunie (pow. zamojski), w tym czasie majątek Aleksandra Szeptyckiego, z pałacem wzniesionym przez Zamoyskich w XVIII w. 
Nieprawdopodobnie byłbym wdzięczny Panu, gdyby mi mógł przysłać jakąkolwiek fotografię pałacu w Łabuńkach, abym się mógł zorientować w jego charakterze. Fotografię tę chętnie zwrócę, jak też równie chętnie będę służył ewentualnie fotografią zrobioną przeze mnie.

Raz jeszcze podkreślam, że udzielone mi pozwolenie na fotografowanie Łabuniek w niczym nie obciąża jego właściciela, i że zabawię tam jak najkrócej, ale proszę nie żądać tylko zapowiedzenia się, bo akuratnie w oznaczonym przeze mnie dniu może padać deszcz, ja zaś, jako student (fil.[ozofii] na U.J.K [Uniwersytecie Jana Kazimierza]) mam za mało środków, aby móc jeździć po kilka razy, względnie czekać aż deszcz przestanie padać. Że pogoda do dobrej fotografii jest konieczna, nie potrzebuję dodawać. Piszę tak wcześnie dlatego, ponieważ porozumiewam się już teraz ze wszystkimi dworami, aby gdy nadejdą odpowiedzi ułożyć sobie już cały plan na wiosenne „łowy” $\mathrm{z}$ aparatem. Czasem ludzie odpowiadają aż po kilku listach, albo zupełnie nie odpowiadają. Jeżeli to może mieć dla Pana jakieś znaczenie, dodaję, że pracuję za namową i ściśle zresztą pod moralnym protektoratem wielu ziemian, m.in. Eleonory ks. Lubomirskiej34, wielkiej miłośniczki tradycji, która chętnie w mojej sprawie udziela wyjaśnień, względnie pośredniczy między osobą, która np. nie znając mnie boi się wpuścić do domu - a mną.

Gdyby mi Pan nie mógł przysłać fotografii, proszę o jedno słówko informacji: czy pałac jest ozdobiony kolumnadą i do której strony świata zwrócony jest fronton. Proszę nie gniewać się za dołączenie koperty na odpowiedź, ale każe mi to czynić doświadczenie, bo inaczej adresat gubi adres, zapomina odpowiedzieć itp. Kopertę posyłam za radą samych zresztą ziemian.

Oczekując rychłej odpowiedzi, proszę przyjąć wyrazy prawdziwego poważania.

Roman Aftanasow

\section{List Romana Aftanasowa do Krystyny Kołaczkowskiej w Łabuńkach ${ }^{35}$}

Morszyn Zdrój, 5.II.1939 [r.]

wielce Szanowna Pani,

ogromnie ucieszyłem się Jej listem i przysłaną mi fotografią. Atmosfera, w którą Jej pismo mnie wprowadza, jest dużym bodźcem do dalszej pracy, albowiem daje mi dowód zrozumienia i życzliwości w stosunku do mych planów.

34 Eleonora z Husarzewskich ks. Lubomirska (1862-1953), żona Andrzeja (1862-1953), właściciela ordynacji przeworskiej. Zob. Teresa Zielińska, Poczet polskich rodów arystokratycznych, Warszawa 1997, s. 154.

35 Przy tym liście zachowała się koperta z adresem: „Jaśnie Wielmożna Krystyna Kołaczkowska w Łabuńkach P[oczta] Zamość skr[ytka pocztowa] 4". Przy znaczku pocztowym odciśnięty stempel z rysunkiem i napisem: „Morszyn: jedyny zdrój wód gorzkich”. 
Fotografii na razie nie odsyłam, ale na pewno zwrócę ją podczas bytności w Łabuńkach. Będę się nią cieszył i widokiem Łabuniek, dokąd ich nie sfotografuję. Tak je sobie wyobrażałem, bo aczkolwiek fotografii nigdzie nie spotkałem, to jednak wszystko, co odnosi się do dworu w Łabuńkach, wypisałem sobie ze Słownika geograficznego i Ruin Polski Szydłowskiego. Jestem więc już nieco co do przeszłości poinformowany. Wiem, że jest jeszcze ładna empireowa brama, z jednym utrąconym wazonem w czasie wojny, była niegdyś duża biblioteka i piękne, stylowe urządzenie z galerią obrazów, z których zdaje się część tylko ocalała. Wokół piękny park. W ogóle o Labuńkach słyszę i czytam same superlatywy. Tylko z listu Wielce Szanownej Pani rozumiem, że Państwo z powodu zniszczenia $\mathrm{w}$ samym pałacu nie mieszkają?

Typ domu, który Łabuńki reprezentują, jest mi bardzo bliski, czy raczej powinienem powiedzieć sympatyczny. I dlatego fotografując Łabuńki będę miał wyjątkową przyjemność. Zresztą każda nowa pozycja w mojej kolekcji jest dla mnie wprost przeżyciem. Dlatego tak uciążliwym jest czekanie na wiosnę...

Szkoda, że dom zwrócony do północy, czyni go to nieco ponurym, a dla fotografowania dość trudnym - nie można mieć żadnych efektów świetlnych. Ale to los większości dworów. Z zamiłowania widocznie nasza szlachta zwracała swe domy ku północy, gdyż znam wiele podobnych wypadków.

Jestem wzruszony Wielce Szanownej Pani gościnnością. Zrozumiałem, że mogę przyjechać autobusem wprost ze Lwowa do Łabuniek. Szalenie mi się to uśmiecha. Wobec tego niżej nakreślę plan mej wyprawy. Z Klemensowem jeszcze nie porozumiałem się. To znaczy dwa razy w zeszłym roku pisałem do Ordynata Maurycego hr. Z[amoyskiego] ${ }^{36}$ i nie otrzymałem odpowiedzi. Byłem zrozpaczony, ale w Przeworsku pocieszyła mnie ks. Eleonora Lubomirska, twierdząc, że ordynat w ogóle na żadne listy nie odpowiada. Wobec tego muszę porozumieć się z którymś z synów. Klemensów chcę zresztą fotografować jedynie z zewnątrz.

Sądzę, że najlepiej będzie, jeśli uczynię tak: Dowiem się, kiedy i skąd (z jakiej ulicy czy placu) odchodzi autobus do Łabuniek, przyjadę nim do Łabuniek i jeśli jeszcze będę miał czas, sfotografuję je. Ponieważ Pani była łaskawa zaproponować mi nocleg we dworze, chętnie $\mathrm{z}$ tego skorzystam. Na drugi dzień udam się do Klemensowa, a jeśli uda się i do Łabuń, sfotografuję oba pałace i jak najprędzej pierwszym możliwym środkiem lokomocji wrócę do Lwowa. Umiem cenić gościnność i dlatego na pewno nie przeciągnę nici, bawiąc w Łabuńkach możliwie najkrócej. Takie rozwiązanie kwestii będzie dla mnie bardzo korzystne, albowiem połączenia kolejowe są fatalne. Pragnę przyjechać w drugiej połowie kwietnia lub w maju. W czerwcu przeszkadzają mi egzaminy na uniwersytecie, lato zaś spędzam częściowo u matki w Morszynie, częściowo u przyjaciół na Polesiu ${ }^{37}$, głównie zaś na rozjazdach. W lipcu i sierpniu będę fotografował głównie Podole.

36 Maurycy hr. Zamoyski (1871-1939), działacz polityczny i społeczny, członek Komitetu Narodowego Polskiego w Paryżu, w 1922 r. był kandydatem na prezydenta, jednocześnie największy posiadacz ziemski II RP (w 1918 r. - ok. 190 tys. ha, w 1939 r. - 64 tys. ha), XV ordynat zamojski.

37 Aftanazy przyjaźnił się z rodziną Ordów, właścicieli Nowoszyc (pow. drohiczyński) na Polesiu, dokąd jeździł na wakacje od początku lat 30. Zob. „Moje curriculum vitae”, s. 2. 
Przepraszam Wielce Szanowną Panią za tak długi list. Spowodowała go uprzejmość Pani, a ja posiadam jedną wielką (prócz mrowia innych) wadę gadatliwości, którą mi trudno opanować, gdy otrzymam wyjątkowo życzliwe pismo. W wędrówkach mych spotykam się bowiem z różnym bardzo przyjęciem, od wysokiej klasy kultury i gościnności, do impertynencji. Ale mimo tego praca moja daje mi wiele radości, gdyż terenem jej jest wieś i dwór. A niektórzy ludzie z tego dworu zostaną mi w pamięci na zawsze. Tak bywają nieprzeciętni i bliscy pojęciowo i zapatrywaniami.

W przybliżeniu postaram się mój przyjazd zapowiedzieć. Sądzę, że jednak przyjadę w kwietniu, bo na maj zbyt długo czekać! A początek wiosny, z pierwszym koncertem żab, bywa najmilszy. Tylko nie wiadomo, jaką tę wiosnę będziemy widzieć w naszym kraju.

Łącząc gorące słowa wdzięczności, proszę Wielce Szanowną Panią przyjąć wyrazy prawdziwego uszanowania.

Roman Aftanasow

Lwów, Gródecka 2b m. 5, „Dom katolicki”, względnie: Morszyn-Zdrój 51 Jeżeli to Panią zainteresuje, przywiozę ze sobą trochę moich fotografii.

\section{List K. Kirkorowej do Krystyny Kołaczkowskiej ${ }^{38}$}

Łabuńki, 20 V 1939 [r.]

Szanowna i Kochana Pani!

Semczuk zawzięcie pracuje koło okien, i drzwi od tarasu już zreperował, teraz robi koło schodów. Malarza jeszcze nie było, ale to i lepiej, bo kurzu moc, więc zaraz by osiadł na czyste ściany. Do świąt wszystko się zrobi. Proszę Pani, jak z pomidorami, ja tu dwie kopy kupiłam, ale bardzo marne, jeżeli Szanowna Pani nie przyśle, to i takich trzeba kupić więcej. Wczoraj czekaliśmy do późna na Szanownych Państwa. Wczoraj przyjechał ten pan [Roman Aftanasow], co to pisał do Pani, no i przenocował i dziś raniutko pojechał do Lwowa. Bardzo miły młody człowiek. Mąż dawał konie mu do Łabuń, no i jeździł z nim do Zamościa. Bardzo był zadowolony.

Szanownej Pani Kołaczkowskiej wyrazy szacunku łączę.

K. Kirkorowa

Serdeczne pozdrowienia

[Rafał] Kirkor

38 List żony administratora Łabuniek, potwierdzający wizytę Romana Aftanazego (Aftanasowa) w majątku w dn. 19-20 maja 1939 r. 


\section{Unknown facts from the biography of Roman Aftanazy (1914-2004)}

Roman Aftanazy (1914-2004), historian, documentalist and long-standing curator of the National Ossoliński Institute Library (initially in Lviv, then in Wrocław), played an important role in Polish historiography as the author of a monumental study on the residences of Polish landed gentry in the former eastern territories of the Polish-Lithuanian Commonwealth (Materiały do dziejów rezydencji, v. 1-11, Warsaw 1986-1991, and the extended $2^{\text {nd }}$ edition: Dzieje rezydencji na dawnych kresach Rzeczypospolitej, v. 1-11, Wrocław 1991-1997). The access to new sources, including Aftanazy's vast legacy archived at the National Ossoliński Institute, allows us to enrich our knowledge of his biography with new details. It has been determined that in 1939, most probably after the outbreak of WWII, the historian had changed his name from Aftanasov on Aftanazy, perhaps for fear of Soviet repression. Moreover, Aftanazy's correspondence from 1939 reveals the shaping of his academic approach during the Interwar period. The material gathered in the historian's legacy provides us with detailed information on his methodology and constitutes an inexhaustible source for further studies on the history of the residences of Polish landed gentry, as well as a valuable source of data on the milieu of former landowners after the last war.

Translated by Jakub Perliński

\section{Неизвестные факты из биографии Романа Афтаназы (1914-2004)}

Роман Афтаназы (1914-2004), историк, документалист и многолетний хранитель Национальной Библиотеки им. Оссолинских во Львове, а затем во Вроцлаве, занимает в польской историографии необыкновенное место, как автор монументального труда о помещичьих усадьбах бывших восточных земель Речи Посполитой (Materiały do dziejów rezydencji, t. 1-11, Warszawa 1986-1991 и второе, дополненное издание этой работы: Dzieje rezydencji na dawnych kresach Rzeczypospolitej, t. 1-11, Wrocław 1991-1997). Доступ к новым источникам, включая обширное наследие историка, находящееся в Оссолинеуме, позволяет обогатить наши знания новыми деталями биографии Афтаназы. Удалось определить, что историк в 1939г., вероятно, уже после начала войны, поменял фамилию с Афтанасов на Афтаназы, возможно, опасаясь советских репрессий. Издаваемые здесь письма историка, датируемые 1939г., в свою очередь, показывают как формировался его научная лаборатория, как он стал вести свои исследования в довоенный период. Материалы, сохранившиеся в наследии историка предоставляют нам дальнейшие сведения о методах работы этого исследователя и являются не только неисчерпаемым источником для последующего изучения истории дворянских усадеб, но и ценной базой данных о среде бывших помещиков после последней войны.

Перевод Агнешка Поспишьль

\section{Bibliografia:}

Aftanazy R., Dzieje rezydencji na dawnych kresach Rzeczypospolitej, t. 1-11, Wrocław 1991-1997. Aftanazy R., Emanuel Małyński, [w:] Polski Słownik Biograficzny, t. XIX.

Aftanazy R., Iłga i Posiń: dwie nieznane rezydencje polskie w Inflantach, „Przegląd Wschodni”, 2004, t. IX, z. 1 (33).

Aftanazy R., Materiały do dziejów rezydencji, t. 1-11, Warszawa 1986-1991.

Aftanazy R., Odpowiedź Tadeuszowi Epszteinowi, „Kwartalnik Historyczny”, R. C, z. 3/1993. 
Aftanazy R., Pacyków - nieznane polskie echo rezydencji Villa Rotonda, „Przegląd Wschodni”, 2000, t. VII, z. 1 (25).

Aftanazy R., Tahańcza: uzupetnienie do dziejów: „Dziejów rezydencji na dawnych kresach Rzeczypospolitej”, „Przegląd Wschodni”, 2000, t. VII, z. 1 (25).

Mossakowski S., Przedmowa, [w:] Roman Aftanazy, Dzieje rezydencji na dawnych kresach Rzeczypospolitej, t. 1, Wrocław 1991.

Baranowski A., Roman Aftanazy 1914-2004, „Przegląd Wschodni”, 2004, t. IX, z. 3 (35), s. 763-766. Epsztein T., Wołyń, Podole i Ukraina w „Materiałach do dziejów rezydencji” Romana Aftanazego, „Kwartalnik Historyczny”, R. C, z. 2/1993, s. 99-104.

Epsztein T., Jeszcze o „Materiałach do dziejów rezydencji”. Odpowiedź na list Romana Aftanazego, „Kwartalnik Historyczny”, R. C, z. 3/1993, s. 179-180.

Epsztein T., Wspomnienie o Romanie Aftanazym (1914-2004), „Studia z Dziejów Rosji i Europy Środkowo-Wschodniej", 2005, t. XL, s. 354-357.

Słownik geograficzny Królestwa Polskiego i innych krajów słowiańskich, t. 1-15, Warszawa 1880-1902.

Szydłowski T., Ruiny Polski: opis szkód wyrządzonych przez wojnę w dziedzinie zabytków sztuki na ziemiach Małopolski i Rusi Czerwonej, Kraków 1919.

Zielińska T., Poczet polskich rodów arystokratycznych, Warszawa 1997.

Ziemianie polscy XX wieku, t. 10, Warszawa 2013.

Tadeusz Epsztein (ur. 1959) - dr hab. prof. IH PAN, zajmuje się m.in. dziejami ziemiaństwa polskiego w XIX i XX wieku, archiwistyką i edycją źródeł. (tadeuszepsztein@o2.pl) 